\title{
Association between substance use and personality among Mexico City's school children aged I0-13
}

\author{
Marco Tulio Suárez Maldonado', Guillermina Natera Rey², Claudia Elena Castillo Lozada' \\ IFacultad de Medicina, Universidad Nacional Autónoma de México, Ciudad de México. \\ ²Dirección de Investigaciones Epidemiológicas y Psicosociales, Instituto Nacional de Psiquiatría Ramón de la Fuente Muñiz, Ciudad de México.
}

\section{RESUMEN}

Introducción: el consumo de sustancias es un problema que requiere estrategias de prevención desde la infancia. Se ha observado que ciertos rasgos de la personalidad pueden jugar un papel importante en el consumo de sustancias en la adolescencia y adultez temprana. El estudio de los factores asociados al consumo de sustancias es esencial para el desarrollo e implementación de intervenciones preventivas. Objetivo: evaluar si los rasgos de desesperanza, búsqueda de sensaciones, impulsividad y sensibilidad a la ansiedad aumentan el riesgo de uso de sustancias (tabaco, alcohol, mariguana e inhalables) en un grupo de infantes escolarizados de la Ciudad de México. Método: estudio transversal exploratorio ex post facto en el que se evaluó el consumo de sustancias y un perfil de personalidad en una muestra no probabilística de 182 infantes escolarizados de 10 a 13 años. Resultados: la prevalencia de consumo de tabaco, alcohol y otras drogas (mariguana e inhalables) fue de $4.4 \%, 28.6 \%$ y $5.5 \%$, respectivamente. Los análisis de regresión logística mostraron que la desesperanza aumenta significativamente el riesgo de consumo de tabaco $(O R=15.883)$ y otras drogas $(O R=15.090)$, mientras que la búsqueda de sensaciones aumenta el riesgo del uso de tabaco $(O R=20.856)$, alcohol $(O R$ $=4.453)$ y otras drogas $(O R=17.139)$. Discusión: el consumo de sustancias fue mayor al estimado por la Encuesta Nacional de Consumo de Drogas en Estudiantes 2014. La desesperanza y búsqueda de sensaciones juegan un papel importante en el consumo de sustancias desde la infancia tardía. Estos resultados tienen implicaciones que pueden ser de utilidad para la prevención.

\section{SUMMARY}

Introduction: substance use is a problem that requires prevention strategies since childhood. It has been noticed that certain personality traits can play an important role in substance use in adolescence and early adulthood. It is essential to study the factors associated with substance use in order to develop and implement preventive interventions. Objective: to evaluate if hopelessness, sensation seeking, impulsivity and anxiety sensibility traits increase the risk of substance use (tobacco, alcohol, marihuana and inhalants) in a group of children enrolled in four primary schools in Mexico City. Methodology: cross sectional exploratory ex post facto survey in which substance use and a personality profile was assessed in a non-randomized sample of 182 children of age 10 to 13. Results: the lifetime prevalence of tobac$\mathrm{co}$, alcohol and other drugs (marihuana and inhalants) use was of $4.4 \%, 28.6 \%$ y $5.5 \%$, respectively. Logistic regression analysis showed that the hopelessness trait significantly increases the risk for use of tobacco (OR $=15.883)$ and other drugs $(O R=15.090)$, while the sensation seeking increases the risk of tobacco $(O R=$ 20.856), alcohol $(O R=4.453)$ and other drugs $(O R$ $=17.139$ ). Discussion: substance use was greater than the estimation in the 2014 Nacional Survey of Drug Use in Students. Hopelessness and sensation seeking play an important role in substance use since late infancy. These results have implications that can help prevention.

Keywords: substance use, personality, children, risk factors, prevention.

Palabras clave: uso de sustancias, personalidad, infantes, factores de riesgo, prevención.

\footnotetext{
Autor de correspondencia:

Marco Tulio Suárez Maldonado. Juan Sánchez Azcona 1631, col. del Valle Sur, Alcaldía Benito Juárez, 3100 , Ciudad de México. Tel.: +52 4431451140 . Correo electrónico: tulio.sumal@gmail.com

Recibido: 7 de junio de 2019

Aceptado: 23 de septiembre de 2019

doi: 10.28931/riiad.2019.2.01
} 


\section{INTRODUCTION}

Substance consumption is a dynamical phenomenon that tends to begin at earlier ages and with that keep increasing prevalence (Villatoro et al., 2016). International literature (European Monitoring Centre for Drugs and Drug Addiction [EMCDDA], 2016; World Health Organization [WHO], 2016) reports that in developed countries in North America and Europe it is estimated that before 13 years old, $17 \%$ of teenagers have already consumed their first cigar, $8 \%$ of them have consumed alcohol reaching drunkenness and $3.5 \%$ have consumed marinuana. In Mexico's case, the most recent Nacional Survey of Drug Use in Students (ENCODE, 2014 [Instituto Nacional de Psiquiatría Ramón de la Fuente, Comisión Nacional Contra las Adicciones, Secretaría de Salud, 2015]) included for the first time a population of children in fifth and sixth grade. The report of this survey shows that in Mexico City the estimated prevalence of "one-time use" (lifetime prevalence), "in the last year" (annual prevalence) and "in the last month" (current prevalence) are, respectively, $5.0 \%, 2.1 \%$ y $1.4 \%$ for tobacco; $18.2 \%, 7.3 \%$ and $3.2 \%$ for alcohol; $1.8 \%, 1.5 \%$ and $1.1 \%$ for marihuana; and $1.0 \%, 1.0 \%$ y $0.5 \%$ for inhalants. Although, the estimated prevalence in Mexico is lower compared to the international data, it is evident that there is a tendency towards the increase of use and a decrease in the initial age of use, for which it has been suggested to implement prevention programs at earlier ages (Villatoro et al., 2016).

There are a set of factors that can increase (risk factors) or decrease (protection factors) the probability of use (Kraemer, Lowe, \& Kupfer, 2005; NIDA, 2003). Psychosocial studies have consistently found that the most relevant factors in childhood appear in the family, school and individual levels (NIDA, 2003b). Regarding the individual level, it has been reported that personality is a factor that can play a very important role in the predisposition, precipitation and perpetuation of substance use (Le Bon et al., 2004).

Evidence suggests that the link between personality traits and substance use can be explained through different motivational processes (Castellanos-Ryan, O'Leary-Barret, \& Conrod, 2013). For example, addictive behavior theories recognize that there are two main types of reinforcement in substance use: positive reinforcement, linked to the positive or hedonic effects of some substances; and the negative reinforcement, linked to the capacity of other substances to alleviate aversive states (Kobb, 2004; Le Bon et al., 2004). As regards, it is supposed that individuals with strong traits of impulsivity or sensation seeking are more sensitive to the positive reinforcement of the substance (e.g., the use of hallucinogens with the intention to reach pleasant states in the consumer), while those with strong traits of sensibility to anxiety and hopelessness are more susceptible to the negative reinforcement of substances (e.g., drinking alcohol with the intention to alleviate feelings of sadness; Krank et al., 2011).

Specifically, it has been found that impulsivity (Díaz \& García-Aurrecoechea, 2008), sensation seeking, anxiety sensitivity and hopelessness traits can predict substance use from age 11 (Castellanos-Ryan, O'Leary-Barret, Sully, \& Conrod., 2013; Castellanos-Ryan \& Conrod, 2012; Jurk et al., 2015; Krank et al., 2011; Robles García et al., 2014; Woicik et al., 2009). Most of these investigations are similar in the metrics they use and in the results they obtain: through the use of Substance Use Risk Profile Scale (SURPS) to evaluate the aforementioned personality traits, they have found a link between the impulsivity trait and the use of stimulant drugs; between sensation seeking and the use of various substances, as well as the frequent use of alcohol and hallucinogens and a link between hopelessness and anxiety sensitivity with sedative drugs like anxiolytics or analgesics (Woicik et al., 2009). Concerning anxiety sensitivity, results are not consistent, as in many cases low correlations or non-significant correlations have been found (e.g., Jurk et al., 2015).

The relevance of studying the factors associated to substance use, like the ones mentioned in this paper, is essential to the screening and the design of adequate preventive interventions (Obot, 2007). As regards, prevention programs during childhood have proved to be a type of intervention more cost effective than the treatment programs (Foxcroft \& Tsertsvadze, 2011).

\section{OBJECTIVE}

The objective of the present study is to assess if four personality traits (impulsivity, sensation seeking, hopelessness and anxiety sensitivity) increase the risk of substance intake (tobacco, alcohol, marihuana and inhalants) in a sample of boys and girls from fifth and sixth grade in south Mexico City. The specific goals are to evaluate these personality traits, estimate the prevalence of substance use, and to evaluate the bivariate and multivariate association between substance use and personality traits.

\section{METHOD}

\section{Design}

Cross sectional exploratory ex post facto survey with the use of a non-probabilistic sample chosen by convenience. 


\section{Scenario and participants}

We included students from fifth and sixth grade from four public schools located in the South part of Mexico City during the school year 2015-2016. All schools were selected by convenience, and they were located in impoverished areas of the city. All scenarios were similar in demographics (see Participants Characteristics in the Results section). We gathered 205 participants, from which we excluded 23 due to lack of answers or inconsistencies in their evaluations, thus, the analyzed sample was of 182 participants ( $47.8 \%$ girls, $68.7 \%$ sixth grade) within an age range of 10 to 13 years old $(M=11.05$, SD $=0.7$ ).

\section{Assessment of the study's variables}

Two questionnaires were applied. The first one explores demographic, family and peer aspects, as well as substance use following three indicators: lifetime use, last year use and last month use. Questionnaire items are based in the survey for elementary schools of ENCODE (2014).

The second questionnaire is the Spanish version of Substance Use Risk Profile Scale (SURPS-MX), a screening instrument for preventive interventions validated for Mexican students of age 11 to 17 (Robles-García et al., 2014). It is a brief questionnaire with 23 Likert-type items (e.g., "I like to do things that scare me a little") with four answer options that rank from 1 (strongly disagree) $\circ 4$ (strongly agree). It measures personality traits that are associated with substance use in four subscales that showed acceptable Chronbach's Alpha coefficients in this sample: Impulsivity $(a=0.63)$, sensation seeking ( $a$ $=0.66)$, hopelessness $(a=0.83)$ and anxiety sensitivity $(a=0.61)$.

\section{Procedure}

First, we approached the authorities of six elementary public schools in the south part of Mexico City. Four of six schools gave permission to perform field work. We invited all fifth and sixth grade students to participate and we explained them (and their parents through a notice) the purpose of the study asking for their children's confidential and anonymous participation. Then we asked their children for their consent to participate in the study.

We obtained informed consents and authorizations of all participants, anonymity was kept using codes instead of names. Afterwards, a trained facilitator performed the application of the questionnaires in all fifth and sixth grades in each school. All of the items were read out loud to participants, giving everyone enough time to choose their answer, and addressing doubts when needed. Each group was comprised of 12 to 23 students and the duration of the application was approximately of 30 minutes. The capture and analysis of data was made in SPSS v.21.

\section{Analysis}

We performed frequency analysis for the description of the sample as well as to determine the lifetime, annual and current prevalence of the use of tobacco, alcohol and "other substances" (variable comprised by the participants that used either or both marihuana and/or inhalants).

Subsequently we made $X^{2}$ tests to evaluate differences in relation to sex. For the personality profile analysis, we scored the SURPS-MX in order to determine the prevalence of the personality traits. Lastly, we made bivariate correlation analysis $\left(X^{2}\right)$ between personality traits and the use of each substance. The personality variables that were significantly associated with use were included in a model of binary logistic regression to determine in which measure each one increases the risk of using the substances.

\section{RESULTS}

\section{Participants characteristics}

Regarding the family structure, $58.7 \%$ of the participants reported living with both parents, 33.5\% live only with her mother, $6.6 \%$ live with their father and $1.2 \%$ live in reconstituted families. With regard to parent training, $23.1 \%$ of the fathers have professional studies and $29.1 \%$ of the mothers do. Additionally, $68.6 \%$ reported that their family always has money for basic needs (food, transportation, home services, clothing and school supplies), while $36.5 \%$ reported that they always have money for other non-basic necessities. Furthermore, 16.5\% reported that they have at least one friend that smokes cigarettes, $15.4 \%$ that they consume alcoholic beverages and 7.7\% that they consume illicit drugs (Table 1).

\section{Prevalence of substance use}

The results indicate that the most consumed substance was alcohol, with a lifetime, annual and current prevalence of $28.6 \%, 11.5 \%$ and $1.6 \%$ respectively. The following was "other drugs" which prevalence $5.5 \%, 2.7 \%$ and $1.6 \%$. Lastly, tobacco, with $4.4 \%, 1.1 \%$ and $1.1 \%$, respectively.

No significant statistical differences according to sex were observed in any of the prevalence of any type of 
substance (Table 2). In connection with the average age of the first use, the result was of 9.3 years old for alcohol, 8.3 years old for tobacco and 9.4 years old for other substances.

Table 1

Participant's demographics $(N=182)$.

\begin{tabular}{|c|c|c|}
\hline Variable & Frequency & $\%$ \\
\hline \multicolumn{3}{|l|}{ Sex } \\
\hline Girl & 87 & 47.8 \\
\hline Boy & 95 & 52.2 \\
\hline \multicolumn{3}{|l|}{ School grade } \\
\hline 5th & 57 & 31.3 \\
\hline 6th & 125 & 68.7 \\
\hline \multicolumn{3}{|l|}{ Age } \\
\hline 10 & 46 & 25.3 \\
\hline 11 & 86 & 47.3 \\
\hline 12 & 45 & 24.7 \\
\hline 13 & 5 & 2.7 \\
\hline \multicolumn{3}{|l|}{ Family structure } \\
\hline Both parents & 107 & 58.7 \\
\hline Monoparental (mother) & 61 & 33.5 \\
\hline Monoparental (father) & 12 & 6.6 \\
\hline Reconstituted & 2 & 1.2 \\
\hline \multicolumn{3}{|l|}{ Parent's studies } \\
\hline College or higher mother & 42 & 23.1 \\
\hline College or higher father & 53 & 29.1 \\
\hline \multicolumn{3}{|l|}{ Family's monetary capacities } \\
\hline Access to all basic needs & 125 & 68.6 \\
\hline Access to non-basic needs & 66 & 36.5 \\
\hline \multicolumn{3}{|l|}{ Peer drug use } \\
\hline Tobacco & 30 & 16.5 \\
\hline Alcohol & 28 & 15.4 \\
\hline Other drugs & 14 & 7.7 \\
\hline
\end{tabular}

\section{Personality traits}

The results of SURPS-MX indicated that $27.5 \%$ of the study population is above one standard deviation of the mean score on impulsivity (27.4\% for boys, $27.6 \%$ for girls); $19.8 \%$ on sensation seeking (26.3\% for boys, $12.6 \%$ for girls), followed by $21.4 \%$ on anxiety sensitivity (17.9 for boys, $25.3 \%$ for girls), and $15.9 \%$ on the hopelessness trait ( $14.7 \%$ for boys, $17.2 \%$ for girls). Significant differences according to sex were found only for sensation seeking (Table 3)

Regarding accumulation of traits, $49.5 \%$ had at least one factor: this percentage is comprised by $24.7 \%$ of the total sample that has only one factor, $18.8 \%$ that have two of them and $7.1 \%$ that have all four traits. There were no significant differences according to sex in these proportions (Table 3).

\section{Relationship between personality and substance use}

On one hand, the analysis of bivariate correlation between personality traits and the use of $s x^{2}$ ubstances (Table 4 ) indicate that hopelessness was highly associated with the use of tobacco (lifetime, annual and current) and other substances (lifetime). On the other hand, impulsivity was associated with tobacco use (lifetime) and other substances (lifetime and annual). In terms of sensation seeking, this was associated with the use of tobacco (lifetime), alcohol (lifetime and annual) and other substances (lifetime and annual). Finally, sensibility to anxiety trait was associated with the use of other substances (lifetime)

Those personality traits significantly associated with the usage of different substances were included in the binary logistic regression models in order to determine what measure they increase the risk of use of the respective substances.

In regards of tobacco use, the results show that hopelessness and sensation seeking increased the risk of use lifetime use 15.88 and 20.85 times respectively.

Table 2

Prevalence of drug use by sex $(N=182)$.

\begin{tabular}{lccccccccc}
\hline & \multicolumn{3}{c}{ Tobacco } & \multicolumn{3}{c}{ Alcohol } & \multicolumn{3}{c}{ Other drugs } \\
& Boys \% & Girls \% & Total \% & Boys \% & Girls \% & Total \% & Boys \% & Girls \% & Total \% \\
\hline Lifetime & 3.2 & 5.7 & 4.4 & 30.5 & 26.4 & 28.6 & 5.3 & 5.7 & 5.5 \\
Last year & 0 & 2.3 & 1.1 & 12.6 & 10.3 & 11.5 & 3.2 & 2.3 & 2.7 \\
Last month & 0 & 2.3 & 1.1 & 3.2 & 0 & 1.6 & 2.1 & 1.1 & 1.6 \\
\hline
\end{tabular}

Note: No statistically significant differences according to sex were found on any prevalence using Chi Square tests $\left(X^{2}\right)$. 
Table 3

Prevalence of personality traits by sex $(N=182)$.

\begin{tabular}{|c|c|c|c|c|c|c|}
\hline \multirow{2}{*}{ Trait } & \multicolumn{5}{|c|}{ Sex } & \multirow[b]{2}{*}{$p$} \\
\hline & $\%$ Total & $\%$ Boys & $\%$ Girls & $x^{2}$ & $d f$ & \\
\hline Impulsivity & 27.5 & 27.4 & 27.6 & .001 & 1 & .974 \\
\hline Sensation seeking & 19.8 & 26.3 & 12.6 & 5.350 & 1 & $.021^{*}$ \\
\hline Anxiety sensitivity & 21.4 & 17.9 & 25.3 & 1.474 & 1 & .225 \\
\hline Hopelessness & 15.9 & 14.7 & 17.2 & .213 & 1 & .645 \\
\hline \multicolumn{7}{|c|}{ Frequency of traits per person } \\
\hline One & 24.7 & 28.4 & 20.7 & 1.458 & 1 & .227 \\
\hline Two & 18.7 & 21.1 & 16.1 & .736 & 1 & .391 \\
\hline Three or four & 7.1 & 5.3 & 9.2 & 1.059 & 1 & .304 \\
\hline
\end{tabular}

Table 4

Bivariate association between personality traits and substance use $(N=182)$.

\begin{tabular}{|c|c|c|c|c|c|c|c|c|c|}
\hline & \multicolumn{3}{|c|}{$\begin{array}{c}\text { Tobacco } \\
x^{2}\end{array}$} & \multicolumn{3}{|c|}{$\begin{array}{c}\text { Alcohol } \\
x^{2}\end{array}$} & \multicolumn{3}{|c|}{$\begin{array}{c}\text { Other drugs } \\
x^{2}\end{array}$} \\
\hline & Lifetime & Last year & Last month & Lifetime & Last year & Last month & Lifetime & Last year & Last month \\
\hline Hopelessness & $16.080^{*}$ & $10.669^{*}$ & $10.669^{*}$ & 1.481 & 2.830 & .689 & $15.339^{*}$ & 2.223 & .578 \\
\hline Impulsivity & $9.486^{\star}$ & .515 & .515 & 1.864 & 2.820 & 2.352 & $9.605^{\star}$ & $7.119^{\star}$ & 2.352 \\
\hline $\begin{array}{l}\text { Sensation } \\
\text { seeking }\end{array}$ & $16.080^{*}$ & 1.164 & 1.164 & $16.012^{*}$ & $7.967^{\star}$ & $12.371^{*}$ & $16.818^{*}$ & $20.851^{*}$ & .353 \\
\hline $\begin{array}{l}\text { Anxiety } \\
\text { sensitivity }\end{array}$ & 4.057 & .552 & .552 & .117 & .080 & 3.708 & $5.130^{\star}$ & 4.543 & 3.708 \\
\hline
\end{tabular}

Notes: ${ }^{*} p<.05 ; X^{2}=$ Chi Square

Table 5

Statistically significant logistic regressions between substance use and personality traits $(N=182)$.

\begin{tabular}{|c|c|c|c|}
\hline Dependent Variable & Independent Variable & OR & $95 \%$ C.I. \\
\hline \multirow[t]{2}{*}{ Lifetime tobacco use } & Hopelessness & 15.883 & {$[2.783,90.651]$} \\
\hline & Sensation seeking & 20.856 & {$[3.310,131.398]$} \\
\hline Lifetime alcohol use & Sensation seeking & 4.453 & {$[2.071,9.574]$} \\
\hline \multirow[t]{2}{*}{ Lifetime other drug use } & Hopelessness & 15.090 & {$[3.067,74.240]$} \\
\hline & Sensation seeking & 17.139 & [3.374, 87.068] \\
\hline
\end{tabular}

Notes: $O R=$ Odds Ratio; C.I. = Confidence Interval; All non-significant models are not included in this table.

On alcohol, we observed that sensation seeking raises the probability for one-time use 4.45 times. On other drugs, the sensation seeking and hopelessness traits increase the risk of lifetime use 15.09 and 17.13 times respectively (Table 5).

\section{DISCUSSION}

This study was carried out in a non-randomized south Mexico City sub-population characterized as public elementary school students that mainly live in families com- 
prised of both parents. The majority of them belong to a low socioeconomic status, whose social life occurs mainly at school, and approximately one in every ten participants had spent time with peers that are substance users.

In this context, we found that the prevalence of alcohol and other substances use were higher than the $2014 \mathrm{EN}$ CODE estimation for a representative sample of Mexico City's children. Additionally, even though in the present study we were not able to prove statistically significant differences in the use by sex, it is important to highlight the fact that the proportions of tobacco use were almost doubled by girls, while the use of alcohol and other drugs was slightly higher among boys.

Another relevant finding is that participants reported more use of other substances (marihuana and/or inhalants) than tobacco, something that has not been reported in the epidemiological records reviewed for this study (EMCDDA, 2016; ENCODE, 2014; Villatoro et al., 2016; $W H O, 2016)$. This can mean that the drugs such as marihuana and inhalants have become equally or more accessible than tobacco. Although national representative data show that most children have a high-risk perception of drug use ( $>90 \%$ consider that the use is dangerous or very dangerous; ENCODE, 2014) it may not be a sufficiently relevant factor for children to avoid use. This information reinforces the argument about the urgency of increasing efforts in prevention since earlier ages. Also, it is relevant that this study found evidence that support the argument that these personality traits play an important role in the use of licit and illicit drugs. These findings can be useful for the development of preventive interventions that target primary school children that have not developed yet a substance use pattern.

It was also found that the SURPS-MX is useful in assessing a personality profile of 10 years old children. SURPS-MX results indicated that $50 \%$ of participants have at least one of the four personality traits assessed. The suppositions of the questionnaire indicate that these participants are at risk of consuming one or another substance, and therefore they could be chosen to participate in a selective preventive program. In this context, the research team that developed the SURPS has also developed a cognitive-behavioral prevention program that addresses these particular personality traits (Preventure Programme; Conrod, 2016). Although this program has not been adapted to the Mexican population yet, we know of a Ph.D. student from the National Autonomous University of Mexico (UNAM) who is currently working on this adaptation.

\section{Limitations}

The principal limitations of this study were that: 1) the sample is non-probabilistic, 2) the size of the sample did not allow the statistical power to evidence in a wider way the association between the studied variables, and 3) the bias possibilities inherent in a self-report questionnaire applied in an infant population.

However, it is considered that the results of this investigation provide a good exploratory contribution, because although the association between personality and the substance use has been consistently reported in high school teenage population, or its equivalents in other countries (e.g., Castellanos-Ryan, O'Leary-Barret, \& Conrod, 2013), it had not been evidenced in Mexican elementary school students. Regarding the self-reports, the analysis of internal consistency were acceptable for personality assessment $(a=0.755)$ and substance use $(a=0.682)$.

\section{CONCLUSIONS}

This study supports the notion that personality traits can play an important role in substance use from childhood, mostly hopelessness and sensation seeking, since these work as risk factors in the starting of usage of tobacco, alcohol, marihuana and/or inhalants.

The assessment of the risk factors (as the one mentioned in this investigation) is primordial in the development and implementation of the selective prevention programs that are more and more necessary. These programs have the benefit of being able to comprehend problems that go beyond the use itself, as it has been observed that this shares a series of risk factors with other dangerous behaviors (e.g., Ritchwood, Ford, DeCoster, Sutton, \& Lochman, 2015). The results of this investigation can add up to the necessary evidence for implementing interventions that attend risk factors in children from fifth to sixth grade.

\section{FUNDING}

None

\section{CONFLICT OF INTEREST}

There are no conflicts of interest regarding the data presented in this study.

\section{REFERENCES}

Castellanos-Ryan, N., \& Conrod, P. J. (2012). Personality and substance misuse: Evidence for a four-factor model of vulnerability. En J. Verster, K. Brady, M. Galanter \& P. J. Conrod (Eds.), Drug Abuse and Addiction in Medical IIIness: Causes, Consequences and Treatment (pp. 47-62). New York, NY: Springer Press. 
Castellanos-Ryan, N., O'Leary-Barret, M., \& Conrod, P. J. (2013). Substance-use in childhood and adolescence: A brief overview of developmental processes and their clinical implications. Journal of the Canadian Academy of Child and Adolescent Psychiatry, 22(1), 41-46.

Castellanos-Ryan, N., O'Leary-Barrett, M., Sully, L., \& Conrod, P. (2013). Sensitivity and specificity of a brief personality screening instrument in predicting future substance use, emotional and behavioral problems: 18-month predictive validity of the Substance Use Risk Profile Scale. Alcoholism: Clinical and Experimental Research, 37, E281-E290. doi: 10.1111/j.15300277.2012.01931.x

Conrod, P. (2016). Personality-Targeted Interventions for Substance Use and Misuse. Current Addiction Reports, 3(4), 426-436. doi: 10.1007/s40429-016-0127-6

Díaz, B., \& García-Aurrecoechea, R. (2008). Factores psicosociales de riesgo de consumo de drogas ilícitas en una muestra de estudiantes mexicanos de educación media. Revista Panamericana de Salud Pública, 24(4), 223-232.

European Monitoring Centre for Drugs and Drug Addiction. (2016). European Drug Report 2016: Trends and Developments. Luxemburgo: Publications Office of the European Union.

Foxcroft, D. R., \& Tsertsvadze, A. (2011). Universal school-based prevention programs for alcohol misuse in young people. The Cochrane Database of Systematic Reviews doi:10.1002/14651858. cd009113

Instituto Nacional de Psiquiatría Ramón de la Fuente Muñiz, Comisión Nacional Contra las Adicciones, Secretaría de Salud. (2015). Encuesta Nacional de Consumo de Drogas en Estudiantes 2014: Reporte de Alcohol. Villatoro J. A., Oliva, N., Fregoso, D., Bustos, M., Mujica A., Martín del Campo, R., Nanni, R., y Medina-Mora, M. E. México, D.F., México: INPRFM 2015.

Jurk, S., Kuitunen-Paul, S., Kroemer, N. B., Artiges, E., Banaschewski, T., Bokde, A. L. W., ...Smolka, M. N. (2015). Personality and substance use: psychometric evaluation and validation of the Substance Use Risk Profile Scale (SURPS) in English, Irish, French, and German Adolescents. Alcoholism: Clinical and Experimental Research, 39(11), 2234-2248. doi:10.1111/acer.12886

Kobb, G. F. (2004). Allostatic view of motivation: Implications for psychopathology. Nebraska Symposium on Motivation, 50, 1-18.

Kraemer, H. C., Lowe, K. K. \& Kupfer, D. J. (2005). To your health. New York, NY: Oxford University Press.

Krank, M., Stewart, S. H., O'connor, R., Woicik, P. B., Wall, A., \& Conrod, P. J. (2011). Structural, concurrent and predictive validity of the
Substance Use Risk Profile Scale in early adolescence. Addictive Behaviors, 36(1-2), 37-46. doi: 10.1016/j.addbeh.2010.08.010

Le Bon, O., Basiaux, P., Streel, E., Tecco, J., Hanak, C., Hansenne, M., Ansseau, M. (2004). Personality profile and drug of choice; a multivariate analysis using Cloninger's TCl on heroin addicts, alcoholics and a random population group. Drug \& Alcohol Dependence, 73(2), 175-182. doi: 10.1016/j.drugalcdep.2003. 10.006

National Institute on Drug Abuse. (2003). What are risk factors and protective factors? Recuperado de https://www.drugabuse. gov/publications/preventing-drug-abuse-among-childrenadolescents/chapter-1-risk-factors-protective-factors/what-arerisk-factors

National Institute on Drug Abuse. (2003b). Preventing Drug Use among Children and Adolescents: A Research-Based Guide for Parents, Educators and Community Leaders. Bethesda, Maryland, United States: NIH Publication.

Obot, I. S. (2007). Limits of substance-use interventions in developing countries. Lancet, 369(9570), 1323-1325. doi: 10.1016/S01406736(07)60373-0

Ritchwood, D. T., Ford, H., DeCoster, J., Sutton, M., \& Lochman, J. E. (2015). Risky sexual behavior and substance use among adolescents: A meta-analysis. Children and Youth Services Review, 52, 74-88. doi: 10.1016/j.childyouth.2015.03.005

Robles-García, R., Fresán, A., Castellanos-Ryan, N., Conrod, P., Gómez, D., De Quevedo y Domínguez, M. E.G., ... MedinaMora, M. E. (2014). Spanish version of the Substance Use Risk Profile Scale: Factor structure, reliability and validity in Mexican adolescents. Psychiatry Research, 220(3), 1113-1117. doi: 10.1016/j.psychres.2014.08.057

Villatoro, J. A., Medina-Mora, M. E., Martín del Campo, R. M., Fregoso, D. A., Bustos, M. N., Reséndiz, E. ... Cañas, V. (2016). El consumo de drogas en estudiantes de México: tendencias y magnitud del problema. Salud Mental, 39(4), 193-203. doi: 10.17711/SM.0185-3325.2016.023

World Health Organization. (2016). Growing up unequal: Gender and socioeconomic differences in young people's health and wellbeing. Health Behavior in School-Aged Children (HBSC) Study: International report from the 2013/2014 survey. Copenhagen, Denmark: WHO Regional Office for Europe.

Woicik, P. A., Stewart, S. H., Pihl, R., \& Conrod P. J. (2009). The substance use risk profile scale: A scale measuring traits linked to reinforcement-specific substance use profiles. Addictive Behaviors, 34(12), 1042-1055. doi: 10.1016/j.addbeh.2009.07.001 